\title{
PENGARUH KESADARAN MEREK, KEPUASAN KONSUMEN DAN KEPERCAYAAN KONSUMEN ATAS MEREK TERHADAP PEMBELIAN ULANGTIKET PESAWAT FIREFLY DI BANDA ACEH
}

\author{
Ika Rahmadani ${ }^{1}$, Tia Risky Ayunda ${ }^{2}$ \\ Universitas Teuku Umar, Meulaboh \\ Email : \\ Universitas Teuku Umar, Meulaboh \\ Email :
}

\begin{abstract}
ABSTRAK
The aim of this research is to know the influence of brand awareness, consumer satisfaction and consumer trust on brand toward the re-purchasing of Firefly airline ticket in Banda Aceh. This study took 99 respondents of re-purchasing of FireFly airline tickets in Banda Aceh. This research was conducted at the Sultan Iskandar Muda airport in Banda Aceh. Data analysis method which used in this research is multiple linear regression. The research results showed that the variables Brand Awareness, consumer satisfaction and consumer trust for brand have significant influence to the repurchasing of Firefly airline tickets in Banda Aceh. In the future, it is expected that the re-purchasing of Firefly airline tickets in Banda Aceh should be able to maintain their brand awareness, consumer satisfaction and consumer trust for brand and to improve other factors which is capable to creating consent to the consumer so that the consumer wants to recommendate to the others.
\end{abstract}

Keywords: Brand awareness, Consumer trust for brand, Cunsumer satisfaction, Repurchasing

\section{PENDAHULUAN}

Seiring dengan perkembangan perekonomian yang semakin pesat, dan tuntutan globalisasi yang membuat tingkat mobilisasi manusia yang semakin cepat, membuat industri yang bergerak di bidang transportasi dan jasa semakin bervariatif. Pesawat terbang menjadi alternatif lain bagi masyarakatuntuk melakukan perjalanan, menggeser peran kereta api dan kapal karena jasa penerbangan dianggap lebih cepat dan efisien. Terlebih lagi dengan lahirnya berbagai perusahaan jasa penerbangan yang menawarkan Low Cost Carrier (LCC) yang menjadikan masyarakat kalangan menengah kebawah pun dapat menikmati bepergian menggunakan pesawat terbang, menjadikan persaingan transportasi jasa penerbangan semakin ketat.

Di era globalisasi dengan tingkat mobilisasi yang tinggi ini, masyarakat mulai menemukan masalah bagaimana melakukan mobilisasi jarak jauh namun dengan waktu yang cepat. Industri jasa transportasi yang semakin maju, menawarkan bebagai macam merek jasa penerbangan. Konsumen sebagai pengambil keputusan menjadi lebih selektif dalam proses pengambilan keputusannya. Dengan adanya persaingan jasa penerbangan yang ketat, perusahaan pun harus melakukan usaha-usaha dalam menarik konsumen agar menggunakan jasa nya. Salah satunya dengan membangun kesadaran merek yang kuat, kepuasan yang tinggi serta kepercayaan atas merek guna membuat konsumen untuk tetap menggunakan produk/jasa nya. 
Suatu pembelian tidak terjadi begitu saja, melainkan ada serangkaian proses tertentu yang dilalui oleh pelanggan. Proses tersebut dimulai dari identifikasi kebutuhan, pencarian informasi, evaluasi terhadap beberapa alternatif, dan melakukan keputusan pembelian hingga terbentuknya perilaku pasca pembelian (Kotler dan Keller, 2011:32). Dalam proses pencarian informasi tentunya konsumen perlu peka terhadap berbagai informasi yang ada disekitar lingkungannya terkait kebutuhan terhadap merek yang akan dibeli. Kepekaan terhadap merek yang akan dibeli ini sangat berkait rapat dengan brand awareness (kesadaran merek).

Kesadaran merek adalah kesanggupan seorang calon pembeli untuk mengenali, mengingat kembali suatu merek sebagai bagian dari suatu kategori produk tertentu (Tjiptono, 2011:97). Bagaimanapun juga, merek yang sudah dikenal menghindarkan calon pembeli dari risiko kerugian karena asumsi calon pembeli adalah bahwa merek yang sudah dikenal dapat diandalkan. Pada umumnya konsumen cenderung membeli produk dengan merek yang sudah dikenalnya atas dasar pertimbangan kenyamanan, keamanan, kepuasan, dan lain-lain.

Kepuasan adalah perasaan senang atau kecewa seseorang yang timbul karena membandingkan kinerja yang dipersepsikan produk (atau hasil) terhadap ekspektasi mereka (Kotler dan Keller, 2011).Konsumen dapat mengalami salah satu dari tiga tingkat kepuasan umum yaitu kalau kinerja di bawah harapan, konsumen akan merasa kecewa tetapi jika kinerja sesuai dengan harapan pelanggan akan merasa puas dan apa bila kinerja bisa melebihi harapan maka pelanggan akan merasakan sangat puas senang atau gembira. Kepuasaan pelanggan membentuk kepercayaan pelaggan yang kemudian menjadi indikasi awal terbentuknya kesetiaan pelanggan.

Blackston seperti dikutip dari Ferrinadewi (2012) menyatakan bahwa kepercayaan adalah salah satu komponen dari keberadaan hubungan pelanggan dengan merek. Suatu transaksi bisnis antar dua pihak atau lebih akan terjadi apabila masing-masing saling mempercayai. Kepercyaan (trust) ini tidak begitu dapat diakui oleh pihak lain/mitra bisnis, melainkan harus dibangun mulai dari awal dan dapat dibuktikan.Menurut Lau dan Lee dalam Tjahyadi (2014:): Kepercayaan pelanggan pada merek (brand trust) didefinisikan sebagai keinginan pelanggan untuk bersandar pada sebuah merek dengan risikorisiko yang dihadapi karena ekspektasi terhadap merek itu akan menyebabkan hasil yang positif. Hawkins (2011) mengatakan bahwa konsumen yang percaya akan suatu merek biasanya akan diikuti dengan melakukan pembelian ulang.

Swasta dan Irawan (2013:26) menyatakan "Pembelian ulang merupakan pembelian yang pernah dilakukan oleh pembeli terhadap suatu produk yang sama dan akan membeli lagi untuk kedua atau ketiga kalinya.Simamora (2012:28) menjelaskan bahwa setiap kali pelanggan membeli, ia akan bergerak melalui siklus pembelian, yaitu pembelian, evaluasi pasca pembelian, dan keputusan membeli kembali. Urutan dari pembelian, evaluasi pasca pembelian, dan keputusan membeli kembali akan berulang beberapa kali, atau beberapa ratus kali, selama terjalin hubungan antara pelanggan dengan perusahaan dan produk serta jasanya. Jika hal ini terus terjadi maka akan tercipta keberlangsungan hidup suatu perusahaan.

Bandara Sultan Iskandarmuda (SIM) di Aceh melayani beberapa merek maskapai komersial, salah satunya adalah Firefly. Pesawat Firefly adalah anak perusahaan maskapai penerbangan Malaysia Airlines yang didirikan pada tanggal 3 April2007. Pembentukan Firefly oleh Malaysia Airlines ini dikarenakan maskapai penerbangan saingannya, Air Asia juga membentuk tiga (3) anak maskapai, yaitu Thai AirAsia, Indonesia AirAsia, dan AirAsia X. Pesawat Firefly melayani berbagai rute domestik di Indonesia, salah satunya rute Banda Aceh-Penang dan Penang-Banda Aceh.

Pada tahun 2015, kita dikejutkan dengan munculnya berita yang menginformasikan bahwa maskapai Firefly secara resmi menghentikan operasionalnya di Pekanbaru. Tahun 2012 Firefly juga telah menghentikan penerbangan di Bandara Internasional Hang Nadim, Batam. Keputusan tersebut 
membuat rute Firefly di Indonesia tinggal di Banda Aceh dan Medan. Pihak maskapai memberikan alasan bahwa surat izin terbang Firefly telah habis. Namun setelah didalami, ternyata penyebab lainnya berkaitan dengan low factor (keterisian penumpang) yang rendah baik di Pekanbaru maupun di Batam (www.regional.kontan.co.id).

Dari fenomena yang disebutkan diatas, peneliti tertarik untuk mengetahui apakah konsumen Firefly di Banda Aceh sadar akan merek, merasa puas dan percaya atas merek yang membuat mereka melakukan pembelian ulang, sehingga sampai sekarang operasional Firefly di Bandara SIM masih berjalan. Penelitian ini akan dimulai dengan menjabarkan kajian kepustakaan, dilanjutkan metode penelitian dan penjabaran hasil penelitian serta ditutup dengan kesimpulan.

\section{KAJIAN KEPUSTAKAAN}

\section{Pengaruh Kesadaran Merek terhadap Pembelian Ulang}

Suyanto (2014 : 80) menyatakan, "Kesadaran merek merupakan kemampuan merek untuk muncul dalam benak konsumen ketika mereka sedang memikirkan produk tertentu dan seberapa mudah nama tersebut dimunculkan. Kesadaran merupakan dimensi dasar dari ekuitas merek. Sebuah merek tidak mempunyai ekuitas sampai konsumen menyadari kesadaran merek tersebut.Merek baru harus mampu mencapai kesadaran merek kemudian semua merek harus berupaya untuk mempertahankan kesadaran merek. Kesadaran konsumen terhadap merek dapat digunakan oleh perusahaan sebagai sarana untuk memberikan pemahaman yang lebih mendalam mengenai suatu merek kepadakonsumen. Perusahaan dapat menciptakan nilai-nilai kesadaran merek agar konsumen dapat lebih memahami pesan merek yang akan disampaikan dan tertarik untuk melakukan pembelian kembali. Beberapa hasil penelitian menemukan bahwa terdapat pengaruh antara kesadaran merek dan keputusan untuk melakukan pembelian ulang (Ariyan, 2012 dan Citranuari, 2015). Berdasarkan uraian diatas, maka hipotesis yang dibangun adalah:

H1: Kesadaran merek berpengaruh positif terhadap pembelian ulang

\section{Pengaruh Kepuasan Konsumen terhadap Pembelian Ulang}

Kepuasan pelanggan didefinisikan sebagai respons pelanggan terhadap ketidaksesuaian antara tingkat kepentingan sebelumnya dan kinerja aktual yang dirasakannya setelah pemakaian (Rangkuti 2002). Kepuasan konsumen pada saat ini menjadi fokus perhatian oleh hampir semua pihak, baik pemerintah, pelaku bisnis, konsumen dan sebagainya. Hal ini disebabkan semakin membaiknya pemahaman mereka atas betapa pentingnya kepuasan bagi seorang konsumen dan juga sebagai strategi untuk dapat memenangkan ersaingan usaha. Kepuasan konsumen merupakan hal yang penting bagi penyedia jasa atau produk, karena konsumen yang merasa puas akan melakukan pembelian kembali. Beberapa penelitian yang menemukan pengaruh positif antara kepuasan konsumen terhadap pembelian ulang diantaranya adalah hasil penelitian Farida (2014), Ishak dan Lutfi (2011) dan Foedjiawati dan Samuel (2005). Berdasarkan uraian diatas, maka hipotesis yang dibangun adalah:

H2: Kepuasan konsumen berpengaruh positif terhadap pembelian ulang

\section{Pengaruh Kepercayaan atas Merek terhadap Pembelian Ulang}

Menurut Lau dan Lee dalam Tjahyadi (2014:71): Kepercayaan pelanggan pada merek (brand trust) didefinisikan sebagai keinginan pelanggan untuk bersandar pada sebuah merek dengan risikorisiko yang dihadapi karena ekspektasi terhadap merek itu akan menyebabkan hasil yang positif. Suatu transaksi bisnis antar dua pihak atau lebih akan terjadi apabila masing-masing saling mempercayai. Kepercyaan (trust) ini tidak begitu dapat diakui oleh pihak lain/mitra bisnis, melainkan harus dibangun mulai dari awal dan dapat dibuktikan. 
Hubungan kepercayaan konsumen atas merek dengan keputusan pembelian ulang diperkuat dengan hasil penelitian Riana (2012:65) yang menunjukkan bahwa secara bersama-sama dan parsial variabel trust in a brand berpengaruh signifikan terhadap brand loyalty dan brand characteristic, company characteristic, consumer - brand characteristic juga berpengaruh signifikan terhadap brand loyalty. Hasil yang sama juga dapat dilihat pada penelitian Wulansari dan Annete (2013), dimana dikemukakan bahwa brand trust dan perceived quality terhadap keputusan pembelian ulang produk Sari Roti. Berdasarkan uraian diatas, maka hipotesis yang dibangun adalah:

H3: Kepuasan konsumen berpengaruh positif terhadap pembelian ulang

\section{METODE PENELITIAN}

\section{Data dan Sumber Data}

Data yang digunakan dalam penelitian ini adalah data primer dengan teknik pengumpulan data menggunakan kuesioner. Penelitian ini dilaksanakan di Bandara tempat pembelian tiket pesawat Firefly yang beralamat di Bandara Sultan Iskandar Muda Banda Aceh. Objek penelitian berhubungan dengan kesadaran merek, kepuasan konsumen dan kepercayaan konsumen atas merekterhadap pembelianulang tiket pesawat Firefly di Banda Aceh

Responden dalam penelitian ini adalah konsumen yang melakukan pembelian ulang pada tiket pesawat Firefly di Banda Aceh. Populasi dalam penelitian ini adalah konsumen yang melakukan pembelian ulang tiket pesawat Firefly tahun 2016 di Banda Aceh selama 6 bulan yaitu Januari, Februari, Maret, April, Mei dan Juni berjumlah 7008 orang.

Berdasarkan perhitungan didapatkan total sampel sebesar 99konsumen yang melakukan pembelian ulang tiket pesawat Firefly di Banda Aceh. Pengambilan sampel menggunakan teknik Accidental Sampling. Menurut Sugiyono (2011:77), Accidental Sampling adalah mengambil responden sebagai sampel berdasarkan kebetulan, yaitu siapa saja yang secara kebetulan bertemu dengan peneliti dapat digunakan sebagai sampel bila orang yang kebetulan ditemui cocok sebagai sumber data. Teknik ini biasanya dilakukan karena keterbatasan waktu, tenaga, dan dana sehingga tidak dapat mengambil sampel yang besar. Penelitian ini menggunakan model analisis regresi linear berganda dengan formula sebagai berikut :

$$
\begin{array}{ll}
\quad \mathbf{Y}=\mathbf{a} & +\mathbf{b}_{\mathbf{1}} \mathbf{X}_{\mathbf{1}}+\mathbf{b}_{\mathbf{2}} \mathbf{X}_{\mathbf{2}}+\mathbf{b}_{\mathbf{3}} \mathbf{X}_{\mathbf{3}}+\mathbf{e} \\
& =\text { Pembelian Ulang } \\
\mathrm{Y} & =\text { Konstanta } \\
\mathrm{a} & =\text { Kesadaran Merek } \\
\mathrm{X}_{1} & =\text { Kepuasan Konsumen } \\
\mathrm{X}_{2} & =\text { Kepercayaan Konsumen atas Merek } \\
\mathrm{X} & =\text { Koefesion } \mathrm{X}_{1}, \mathrm{X}_{2}, \mathrm{X}_{3} \\
\mathrm{~b}_{1}, \mathrm{~b}_{2}, \mathrm{~b}_{3} & =\text { Error Term } \\
\mathrm{e} &
\end{array}
$$

\section{HASIL PENELITIAN DAN PEMBAHASAN}

Untuk melihat pengaruh Kesadaran merek, Kepuasan Konsumen dan Kepercayaan Konsumen Atas Merek terhadap pembelian ulang tiket pesawat Firefly di Banda Aceh dapat dilihat pada Tabel 1 di bawah ini : 
Tabel. 1

Analisis Regresi Linear Berganda

\begin{tabular}{|c|c|c|c|c|c|}
\hline Nama Variabel & Beta & $\begin{array}{c}\text { Standar } \\
\text { Error }\end{array}$ & $\mathbf{t}_{\text {hitung }}$ & $\mathbf{t}_{\text {tabel }}$ & Sig. \\
\hline (Constant) & 0,316 & 0,035 & 6,045 & $\begin{array}{c}1,98 \\
5\end{array}$ & 0,000 \\
\hline $\operatorname{Kesadaran} \operatorname{Merek}\left(\mathrm{X}_{1}\right)$ & 0,723 & 0,057 & $\begin{array}{c}10,13 \\
5\end{array}$ & $\begin{array}{c}1,98 \\
5\end{array}$ & 0,000 \\
\hline $\begin{array}{l}\text { Kepuasan Konsumen } \\
\left(\mathrm{X}_{2}\right)\end{array}$ & 0,298 & 0,048 & 5,341 & $\begin{array}{c}1,98 \\
5\end{array}$ & 0,000 \\
\hline $\begin{array}{l}\text { Kepercayaan } \\
\text { Konsumen Atas Merek } \\
\left(\mathrm{X}_{3}\right)\end{array}$ & 0,386 & 0,059 & 6,591 & $\begin{array}{c}1,98 \\
5\end{array}$ & 0,000 \\
\hline \multicolumn{2}{|c|}{ Koefisien Korelasi $(\mathrm{R})=0,995$} & \multicolumn{4}{|c|}{$\begin{array}{l}\text { a. Predictors : (constanta), } \\
\text { Brand Awereness, } \\
\text { Kepuasan Konsumen dan } \\
\text { Kepercayaan Konsumen } \\
\text { Atas Merek }\end{array}$} \\
\hline \multirow{2}{*}{\multicolumn{2}{|c|}{$\begin{array}{l}\text { Koefisien Determinasi }\left(\mathrm{R}^{2}\right)=0,985 \\
\text { tiket pesawat } \\
\text { Adjusted }\left(\mathrm{R}^{2}\right)=0,989\end{array}$}} & \multicolumn{4}{|c|}{ b. Variabel Pembelian ulang } \\
\hline & & \multicolumn{4}{|c|}{ Firefly di Banda Aceh } \\
\hline
\end{tabular}

Tabel 2

Table Analysis of Variance (ANOVA)

\begin{tabular}{crrrrrr}
\hline Model & $\begin{array}{c}\text { Sum of } \\
\text { Squeres }\end{array}$ & Df & $\begin{array}{c}\text { Mean } \\
\text { Squeres }\end{array}$ & F-hitung & $\begin{array}{c}\text { F- } \\
\text { tabel }\end{array}$ & Sig \\
\hline Regresi & 59,353 & 3 & 37,2661 & 4741,12 & 3,091 & $0.000^{\text {a }}$ \\
Sisa & 0,597 & 96 & 0,006 & & & \\
Total & 59,950 & 99 & & & & \\
\hline
\end{tabular}

Pengujian Secara Bersama-sama (Uji F)

Sumber: Data diolah (2016)

\section{Pengujian Secara Bersama-sama}

Pengujian terhadap kesadaran merek, kepuasan konsumendan kepercayaan konsumen atas merek terhadap pembelian ulang tiket pesawat Firefly di Banda Aceh digunakan uji F. F-hitung dalam persamaan ini adalah sebesar 4741,12sedangkan $\mathrm{F}_{\text {-tabel }}$ sebesar 3,091. Berdasarkan Tabel 2 di atas dapat dilihat bahwa pada tingkat signifikansi $5 \%$ nilai $\mathrm{F}_{\text {-hitung }}>\mathrm{F}_{\text {-tabel }}$ maka dapat diartikan bahwa secara serentak terdapat pengaruh kesadaran merek, kepercayaan konsumen dan kepercayaan konsumen atas merek terhadappembelian ulang tiket pesawat Firefly.

\section{Pengaruh Kesadaran Merek terhadap Pembelian Ulang Tiket Pesawat Firefly}

Kesadaran merek merupakan salah satu alat yang dapat dimanfaatkan oleh perusahaan untuk membuat produknya selalu diingat oleh konsumen. Suatu merek yang sudah melekat pada pikiran konsumen terhadap suatu produk, akan menciptakan keunggulan bersaing yangmemiliki nilai tambah. Ketika konsumen merasa sudah mengenali, mampu mengingat sebuah merek dengan baik, dan merasa 
sudah cukup dekat dengan merek tersebut, maka akan semakin tinggi kemungkinan konsumen memutuskan membeli kembali merek tersebut.

Hasil penelitian menunjukkan bahwa ada pengaruh positif kesadaran merek terhadap keputusan pembelian ulang tiket pesawat Firefly . Hal ini dibuktikan dengan hasil statistik uji t untuk kesadaran merek diperoleh nilai t hitung sebesar 10,135 dengan nilai signifikansi sebesar 0,000 lebih kecil dari 0,05 dan koefisien regresi mempunyai nilai positif sebesar 0,723 . Hasil temuan ini sejalan dengan hasil penelitian dari Ariyan (2012) dan Citranuari (2015).

\section{Pengaruh Kepuasan Konsumen terhadap Pembelian Ulang}

Konsumen merupakan satu-satunya alasan hidup dan tumbuhnya suatu perusahaan.Alasan ini menyebabkan kepuasan konsumen menjadi prioritas utama bagi perusahaan.Kepuasan konsumen yang berujung pada tuntutan konsumen sehingga konsumen tidak hanya menginginkan kualitas produk dengan harga relatif murah tetapi juga kemudahan untuk mendapatkan produk.

Hasil penelitian menunjukkan bahwa ada pengaruh positif kepuasan konsumen terhadap keputusan pembelian ulang tiket pesawat Firefly. Hal ini dibuktikan dengan hasil statistik uji t untuk kepuasan konsumen diperoleh nilai t hitung sebesar 5,341 dengan nilai signifikansi sebesar 0,000 lebih kecil dari 0,05 dan koefisien regresi mempunyai nilai positif sebesar 0,298. Hasil penelitian menunjukkan bahwa kepuasan konsumen berpengaruh signifikan terhadap pembelian ulang, yang artinya, semakin tinggi kepuasan konsumen semakin tinggi pula pembelian ulang.Kesesuain kepuasan yang diperoleh konsumen dapat meningkatkan pembelian ulang. Hasil temuan ini sejalan dengan hasil penelitian dari Farida (2014), Ishak dan Lutfi (2011) dan Foedjiawati dan Samuel (2005).

\section{Pengaruh Kepercayaan Konsumen atas Merek terhadap Pembelian Ulang}

Rasa percaya konsumen terhadap suatu merek berdampak pada keputusan seseorang untuk kembali membeli merek tersebut. Ketika konsumen merasa merek yang dipilih telah sesuai harapan dan tidak merasa kecewa ketika menggunakan merek tersebut, maka akan semakintinggi tingkat keputusan untuk kembali membeli merek tersebut dimasa datang. Begitu juga sebaliknya, ketika konsumen merasa kecewa membeli merek tersebut, dan merasa apa yang dibutuhkan tidak mampu terpenuhi, maka tingkat keputusan pembelian ulang akan sangat rendah.

Hasil penelitian menunjukkan bahwa ada pengaruh positif kepercayaan konsumen atas merek terhadap keputusan pembelian ulang tiket pesawat Firefly . Hal ini dibuktikan dengan hasil statistik uji $\mathrm{t}$ untuk kepuasan konsumen diperoleh nilai t hitung sebesar 6,591 dengan nilai signifikansi sebesar 0,000 lebih kecil dari 0,05 dan koefisien regresi mempunyai nilai positif sebesar 0,386 . Hasil penelitian menunjukkan bahwa kepercayaan konsumen atas merek berpengaruh signifikan terhadap pembelian ulang, yang artinya, semakin tinggi kepercayaan konsumen atas merek semakin tinggi pula pembelian ulang. Hasil temuan ini sejalan dengan hasil penelitian dari Wulansari dan Annete (2013) dan Riana (2012).

Dari hasil penelitian yang diperoleh, dapat disimpulkan bahwa kepercayaan konsumen terhadap merek merupakan faktor yang penting agar perusahaan mampu membuat produknya dapat menjadi solusi dalam memenuhi kebutuhan konsumennya. Konsumen yang percaya akan merek tersebut akan menimbulkan loyalitas yang nantinya dapat terjadinya pembelian ulang. 


\section{KESIMPULAN DAN SARAN}

\section{Kesimpulan}

Dari hasil pengujian dan analisis yang telah dilakukan dapat diambil kesimpulan sebagai berikut:

1. Kesadaran merek, kepuasan konsumen dan kepercayaan konsumen atas merek secara serentak atau bersama-sama mempunyai pengaruh yang signifikan terhadap pembelian ulang tiket pesawat Firefly di Banda Aceh.

2. Kesadaran merek mempunyai pengaruh positif dan signifikan terhadap pembelian ulang tiket pesawat Firefly di Banda Aceh.

3. Kepuasan konsumen memiliki pengaruh positif dan signifikan terhadap pembelian ulang tiket pesawat Firefly.

4. Kepercayaan konsumen atas merek yang mempunyai pengaruh positif dan signifikan terhadap pembelian ulang tiket pesawat Firefly di Banda Aceh

\section{Saran}

1. Diharapkan kepada karyawan dan pimpinan pada loket pembelian tiket pesawat Firefly di Banda Aceh untuk dapat mempertahankan faktor kesadaran merek, kepuasan konsumen dan kepercayaan konsumen atas merekserta dapat meningkatkan faktor tersebut, kemudian memperhatikan juga faktor lain yang mempengaruhi pembelian ulang.

2. Penelitian ini diharapkan dapat menjadi masukan bagi para peneliti selanjutnya yang ingin meneliti pada objek yang sama, hendaknya juga memasukkan unsur lain selain dari variabel yang telah dibahas seperti loyalitas nasabah. 


\section{DAFTAR KEPUSTAKAAN}

Ariyan, Hendi. (2012). Pengaruh Brand Awareness Dan Kepercayaan Konsumen Atas Merek Terhadap Keputusan Pembelian Ulang Minuman Aqua Di Kota Padang. E-Journal Universitas Negeri Padang. Hlm: 1-11.

Citranuari,S.J. (2015). Pengaruh Kepercayaan Merek, Kesadaran Merek dan Persepsi Kualitas terhadap Keputusan Pembelian Ulang: Studi Pada Konsumen Produk Kecantikan Ponds di Universitas Negeri Yogyakarta. Jurnal Ilmu Manajemen. Vol.3 No.4, hlm:23-34.

Farida, Naili. (2014). Analisis Model Kepuasan terhadap Pembelian Ulang. Dinamika Manajemen. Vol. 5 No.2, hlm: 200-208.

Ferrinadewi, Erna dan S. Pantja Djati (2012), Pentingnya Karyawan dalam Pembentukan Kepercayaan Konsumen Terhadap Perusahaan Jasa. Jurnal Ekonomi Manajemen. Vol.15 No.2, Hlm: 97-109.

Foedjiawati dan Samuel, H. (2005). Pengaruh Kepuasan Konsumen terhadap Kesetiaan Merek (Studi Kasus Restoran The Prime Steak \& Ribs Surabaya). Jurnal Manajemen dan Kewirausahaan. Vol.7 No.1, hlm: 74-82.

Hawkins, Del I (2011). Consumer Behavior: Building Marketing Strategy. New York: Irwin McgrawHill.

Ishak, A dan Lutfi, Z. (2011). Pengaruh Kepuasan dan Kepercayaan Konsumen terhadap Loyalitas: Studi tentang Peran Mediasi Switching Cost. Jurnal Siasat Bisnis. Vol.15 No.1, hlm: 56-68.

Kotler, keller . (2011) Manajemen Pemasaran, Edisi Kesebelas, Jilid I,Jakarta, PT Indeks.

Rangkuti, F. (2002). Measuring Customer Satisfaction Gaining Customer Relationship Strategy Teknik Mengukur dan Strategi Meningkatkan Kepuasan Pelanggan \& Analisis Kasus PLN-JP. Jakarta (ID): Penerbit PT Gramedia Pustaka Utama.

Riana, Gede. (2012). Pengaruh Trust in a Brandterhadap Brand Loyaltypada Konsumen Air Minum Aqua Di Kota Denpasar.” Buletin Studi Ekonomi. Vol. 13 No. 2, hlm: 20-29.

Simamora. (2012). Brand Management \& Strategy. Yogyakarta: Andi.

Sugiyono.(2011).Metode Penelitian Bisnis, Bandung: Alfabeta.

Suyanto (2014). Marketing Strategy Top Brand Indonesia, Yogyakarta: Andi.

Swasta, Bayu dan Irawan. (2013). Manajemen Pemasaran Modern. Yogyakarta. Penerbit Liberti.

Tjahyadi, Rully Arlan. (2014). Peranan Trustdalam Konteks Loyalitas Merek:Peran Karakteristik Merek, Karakteristik Perusahaan, Dan Karakteristik Hubungan Pelanggan Merek. Jurnal Manajemen. Vol. 6, No.1, hlm: 12-21. 
Tjiptono, Fandy. (2011) Brand Management \& Strategy.Yogyakarta: Andi.

Wulansari, Anette (2013). Pengaruh Brand Trustdan Perceived Qualityterhadap Keputusan Pembelian Ulang. Jurnal Ilmu Manajemen. Vol. 1 No. 2, hlm:388-40.

www. regional.kontan.co.id/news/gapura-angkasa-kehilangan-firefly-di-pekanbaru. (2015) Gapura Angkasa Kehilangan Firefly di Pekanbaru. Diakses 23 Maret 2016. 